There is a pluralist America but not two Americas. This is so because good lawyers wrote good law, and made of the "no-estab. lishment" and the "free exercise" clauses of the first Amendment not articles of faith but articles of peace.

\title{
THE PROBLEM \\ OF PLURALISM IN AMERICA
}

JOHN COURTNEY MURRAY

The problem of pluralism has a twofold origin. It arises, first, from the coexistence within the political community of groups who hold divergent views with regard to ultimate questions concerning the nature and destiny of man. Such questions are basically religious. Pluralism therefore implies a plurality of incompatible religious faiths; it implies disagreement and dissension within the community. On the other hand, pluralism also implies agreement, unity, a certain consensus. The various groups form one community; they agree to live in peace; they all cooperate toward the achievement of the temporal goals of the community. This cooperation toward the common good supposes a certain consensus. In particular, the various groups despite their differences give common consent to the political and legal provisos in which the pluralism of the community finds expression in the structure of the state. Pluralism therefore means harmony amid discord; it means a harmony of social life and political action amid a discord of religious creeds and modes of worship.

If society is to be a rational process, some set of principles must motivate the general participation of all religious groups in the social consensus and their common allegiance to the laws which reflect the pluralism of the society. At the same time these principles must not hinder the maintenance by each group of its own 
distinct identity. From the theoretical point of view, therefore, the problem of pluralism is twofold. First, on what theory is the plurality within the community accepted, in such wise that it does not destroy the necessary social unity? Second, on what theory is the consensus of the community based, in such wise that it does not infringe upon the plurality, but permits to all the differing groups the full integrity of their own convictions?

As it arose in America, the problem of pluralism was unique in the modern world, chiefly because pluralism was the native condition of American society. It was not, as in Europe and in England, the result of a disruption or decay of a previously existent religious unity. This fact created the possibility of a new solution; indeed, it created a demand for a new solution. The possibility was exploited and the demand was met by the American Constitution.

The question here concerns the position of the Catholic conscience in the face of the new American solution to a problem that for centuries has troubled, and still continues to trouble, various nations and societies. A new problem has been put to the universal Church by the fact of America-by the uniqueness of our social situation, by the genius of our newly conceived constitutional system, by the lessons of our singular national history, which has molded in a special way the consciousness and temper of the American people, within whose midst the Catholic stands, sharing with his fellow citizens the same national heritage. The Catholic community faces the task of making itself intellectually aware of the conditions of its own coexistence within the American pluralistic scene. We have behind us a lengthy historical tradition of acceptance of the special situation of the Church in America, in all its differences from the situations in which the Church elsewhere finds herself. But it is a question here of pursuing the subject, not in the horizontal dimension of history but in the vertical dimension of history.

The argument readily falls into two parts. The first part is an analysis of the American proposition with regard to social unity. The effort is to make a statement of the essential contents of the American consensus, whereby we are made "e pluribus unum," one society subsisting amid multiple pluralisms. Simply to make this statement is to show why American Catholics participate with ready conviction in the American consensus. The second part is an analysis 
of the American proposition with regard to religious pluralism, especially as this proposition is embodied in our fundamental law. Again, simply to make this analysis is to lay bare the reasons why American Catholics accept on principle the unique American solution to the age-old problem.

In pursuing the argument it is taken for granted that the principles of Catholic faith and morality are controlling. Religious faith and morals are not subject to judgment by the norms of any political and social system. The question sometimes raised, whether Catholicism is compatible with American democracy, is an invalid and impertinent question; for the manner of its position inverts the order of values. The question is whether American democracy-in our case as involving a theory of pluralism-is compatible with Catholicism. No other manner of putting the question would be acceptable to anyone who places the imperatives of consciences, which mediate the law of God, above the imperatives whose origins are in human law and sentiment.

\section{Unity Amid Plurality}

The term, "American proposition," is here taken in a pregnant sense. It means the whole organized constellation of principles and ideas, values and sentiments, techniques and institutions, in terms of which the American people interpret to themselves their society, their state, their government, their political and social ideals and the method of their achievement - in a word, themselves as a people organized for action in history. In this sense the American proposition is a very complicated thing, not without its inconsistencies and ambiguities. No full analysis of it is attempted here. Only a few relevant aspects are selected.

First of all, every proposition supposes an epistemology of some kind. The Declaration of Independence made clear what the epistemology of the American proposition is, in the noted phrase: "We hold these truths to be self-evident. . ." Today, when the serene, not to say naive, certainties of the eighteenth century have passed away, the self-evidence of the truths is legitimately questioned by the sophisticated. What cannot be questioned by anybody is that 
the American proposition starts with the forthright assertion of a bit of realist epistemology: "There are truths, and we hold them." The political and social life of man does not ultimately rest upon such tentative empirical hypotheses as the positivist may cast up. The dynamism of society is not furnished, as in Marxist theory, by certain ideological projections of economic interests. The principles of politics are not regarded as operational tools with which to further at any given juncture the dialectic processes of history. On the contrary, the life of man in society under government is founded on truth, on certain objective truths, universal in their import, accessible to man, definable, defensible. If this assertion be denied, the American proposition is eviscerated at one stroke. It is indeed in many respects a pragmatic proposition; but as a whole it does not rest on the philosophy of pragmatism. For the pragmatist there are properly speaking no truths, only results. But the American proposition rests on the more traditional conviction that truths are, and that they can be known.

\section{This Nation Under GoD}

The first truth to which the American Proposition makes appeal is likewise stated in that landmark of Western political theory, the Declaration of Independence. It is a truth that lies beyond politics; it imparts to politics a fundamental human meaning. I mean the sovereignty of God over nations as well as over individual men. This is the principle that radically distinguishes the conservative Christian tradition of America from the Jacobin laicist tradition of Continental Europe. The Jacobin tradition proclaimed the autonomous reason of man to be the first and the sole principle of political organization. In contrast, the first article of the American political faith is that the political community, as a form of free and ordered human life, looks to the sovereignty of God as to the first principle of its organization. In the Jacobin tradition religion is at best a purely private concern, a matter of personal devotion, quite irrelevant to public affairs; society as such, and the state which gives it legal form, and the government which is its organ of action are by definition agnostic or atheist; the statesman as such cannot be a believer, and his actions as a statesman are immune from any imperative or judgment higher than the will of the people, in whom resides ultimate and total 
sovereignty (one must remember that in the Jacobin tradition "the people" means "the party"). This whole manner of thought is altogether alien to the authentic American tradition.

From the point of view of the problem of pluralism this radical distinction between the American and the Jacobin traditions is of cardinal importance. The United States has had, and still has, its share of agnostics and unbelievers. But it has never known organized militant atheism on the Jacobin, doctrinaire Socialist, or Communist model; it has rejected parties and theories which erect atheism into a political principle. In 1799, the year of the Napoleonic coup d'état which overthrew the Directory and established a dictatorship in France, President John Adams stated the first of all American first principles in his remarkable proclamation of March 6:

$\ldots$ it is also most reasonable in itself that men who are capable of social acts and relations, who owe their improvements to the social state, and who derive their enjoyments from it, should, as a society, make acknowledgements of dependence and obligation to Him who hath endowed them with these capacities and elevated them in the scale of existence by these distinctions....

President Lincoln on May 30, 1863, echoed the tradition in another proclamation:

Whereas the Senate of the United States, devoutly recognizing the supreme authority and just government of Almighty God in all the affairs of men and nations, has by a resolution requested the President to designate and set apart a day for national prayer and humiliation; And whereas it is the duty of nations as well as of men to own their dependence upon the overruling power of God, to confess their sins and trespasses in humble sorrow, yet with the assured hope that genuine repentance will lead to mercy and pardon. ...

The authentic voice of America speaks in these words. And it is a testimony to the enduring vitality of this first principle - the sovereignty of God over society as well as over individual men - that President Eisenhower in June, 1952, quoted these words of Lincoln in a proclamation of similar intent. There is, of course, dissent from this principle, uttered by American secularism (which, at that, is a force far different in content and purpose from Continental laicism). But the secularist dissent is clearly a dissent; it illustrates the existence of the American affirmation. And it is continually challenged. For instance, as late as 1952 an opinion of the United States 
Supreme Court challenged it by asserting: "We are a religious people whose institutions presuppose a Supreme Being." Three times before in its history - in 1815, 1892, and 1931-the Court has formally espoused this same principle.

\section{The Tradition of Natural LaW}

The affirmation in Lincoln's famous phrase, "this nation under God," sets the American proposition in fundamental continuity with the central political tradition of the West. But this continuity is more broadly and importantly visible in another, and related, respect. In 1884 the Third Plenary Council of Baltimore made this statement: "We consider the establishment of our country's independence, the shaping of its liberties and laws, as a work of special Providence, its framers 'building better than they knew,' the Almighty's hand guiding them." The providential aspect of the matter, and the reason for the better building, can be found in the fact that the American political community was organized in an era when the tradition of natural law and natural rights was still vigorous. Claiming no sanction other than its appeal to free minds, it still commanded universal acceptance. And it furnished the basic materials for the American consensus.

The evidence for this fact has been convincingly presented by Clinton Rossiter in his book, Seedtime of the Republic, a scholarly account of the "noble aggregate of 'self-evident truths' that vindicated the campaign of resistance (1765-1775), the resolution for independence (1776), and the establishment of the new state governments (1776-1780)." These truths, he adds, "had been no less self-evident to the preachers, merchants, planters, and lawyers who were the mind of colonial America." It might be further added that these truths firmly presided over the great time of study, discussion, and decision which produced the Federal Constitution. "The great political philosophy of the Western world," Rossiter says, "enjoyed one of its proudest seasons in this time of resistance and revolution." By reason of this fact the American Revolution, quite unlike its French counterpart, was less a revolution than a conservation. It conserved, by giving newly vital form to, the liberal tradition of politics, whose ruin in Continental Europe was about to be consummated by the first great modern essay in totalitarianism.

The force for unity inherent in this tradition was of decisive im- 
portance in what concerns the problem of pluralism. Because it was conceived in the tradition of natural law the American Republic was rescued from the fate, still not overcome, that fell upon the European nations in which Continental Liberalism, a deformation of the liberal tradition, lodged itself, not least by the aid of the Lodges. There have never been "two Americas," in the sense in which there have been, and still are, "two Frances," "two Italys," "two Spains." Politically speaking, America has always been one. The reason is that a consensus was once established, and it still substantially endures, even in the quarters where its origins have been forgotten.

Formally and in the first instance this consensus was political, that is, it embraced a whole constellation of principles bearing upon the origin and nature of society, the function of the state as the legal order of society, and the scope and limitations of government. "Free government"-perhaps this typically American shorthand phrase sums up the consensus. "A free people under a limited government" puts the matter more exactly. It is a phrase that would have satisfied the first Whig, St. Thomas Aquinas.

To the early Americans government was not a phenomenon of force, as the later legal positivists would have it. Nor was it a "historical category," as Marx and his followers were to assert. Government did not mean simply the power to coerce, though this power was taken as integral to government. Government, properly speaking, was the right to command. It was authority. And its authority derived from law. By the same token its authority was limited by law. In his own way Tom Paine put the matter when he said, "In America Law is the King." But the matter had been better put by Henry of Bracton (d. 1268) when he said, "The king ought not to be under a man, but under God and under the law; because the law makes the king." This was the message of Magna Charta; this became the first structural rib of American constitutionalism.

Constitutionalism, the rule of law, the notion of sovereignty as purely political and therefore limited by law, the concept of government as an empire of laws and not of men - these were ancient ideas, deeply implanted in the British tradition at its origin in medieval times. The major American contribution to the tradition - a contribution that imposed itself on all subsequent political history in the Western world-was the written constitution. However, the Amer- 
ican document was not the constitution octroyée of the nineteenthcentury Restorations - a constitution graciously granted by the King or Prince-President. Through the American techniques of the constitutional convention and of popular ratification, the American Constitution is explicitly the act of the people. It embodies their consensus as to the purposes of government, its structure, the extent of its powers and the limitations on them, etc. By the Constitution the people define the areas where authority is legitimate and the areas where liberty is lawful. The Constitution is therefore at once a charter of freedom and a plan for political order.

\section{The Principle of Consent}

Here is the second aspect of the continuity between the American consensus and the ancient liberal tradition; I mean the affirmation of the principle of the consent of the governed. Sir John Fortescue, (d. 1476) Chief Justice of the Court of King's Bench under Henry VI, had thus stated the tradition, in distinguishing between the absolute and the constitutional monarch: "The secounde king [the constitutional monarch] may not rule his people by other laws than such as thai assenten to. And therefore he may set uppon thaim non "mposicions without their consent." The principle of consent was inherent in the medieval idea of kingship; the king was bound to seek the consent of his people to his legislation. The American consensus reaffirmed this principle, at the same time that it carried the principle to newly logical lengths. Americans agreed that they would consent to none other than their own legislation, as framed by their representatives, who would be responsible to them. In other words, the principle of consent was wed to the equally ancient principle of popular participation in rule. But, since this latter principle was given an amplitude of meaning never before known in history, the result was a new synthesis, whose formula is the phrase of Linsoln, "government by the people."

Americans agreed to make government constitutional and therefore limited in a new sense, because it is representative, republican, responsible government. It is limited not only by law but by the will of the people it represents. Not only do the people adopt the Constitution; through the techniques of representation, free elections, and frequent rotation of administrations they also have a share in the 
enactment of all subsequent statutory legislation. The people are really governed; American political theorists did not pursue the Rousseauist will-o'the-wisp: How shall the individual in society come to obey only himself? Nevertheless, the people are governed because they consent to be governed; and they consent to be governed because in a true sense they govern themselves.

The American consensus therefore includes a great act of faith in the capacity of the people to govern themselves. The faith was not unrealistic. It was not supposed that everybody could master the technical aspects of government, even in a day when these aspects were far less complex than they now are. The supposition was that the people could understand the general objectives of governmental policy, the broad issues put to the decision of government, especially as these issues raised moral problems. The American consensus accepted the premise of medieval society, that there is a sense of justice inherent in the people, in virtue of which they are empowered, as the medieval phrase had it, to "judge, direct, and correct" the processes of government.

It was this political faith that compelled early American agreement to the institutions of a free speech and a free press. In the American concept of them, these institutions do not rest on the thin theory proper to eighteenth-century individualistic rationalism, that a man has a right to say what he thinks merely because he thinks it. The American agreement was to reject political censorship of opinion as unrightful, because unwise, imprudent, not to say impossible. However, the proper premise of these freedoms lay in the fact that they were social necessities. "Colonial thinking about each of these rights had a strong social rather than individualistic bias," Rossiter says. They were regarded as conditions essential to the conduct of free, representative, and responsible government. People who are called upon to obey have the right first to be heard. People who are to bear burdens and make sacrifices have the right first to pronounce on the purposes which their sacrifices serve. People who are summoned to contribute to the common good have the right first to pass their own judgment on the question, whether the good proposed be truly a good, the people's good, the common good. Through the technique of majority opinion this popular judgment becomes binding on government. 
A second principle underlay these free institutions - the principle that the state is distinct from society and limited in its offices toward society. This principle too was inherent in the Great Tradition. Before it was cancelled out by the rise of the modern omnicompetent society-state, it had found expression in the distinction between the order of politics and the order of culture, or, in the language of the time, the distinction between studium and imperium. The whole order of ideas in general was autonomous in the face of government; it was immune from political discipline, which could only fall upon actions, not ideas. Even the medieval Inquisition respected this distinction of orders; it never recognized a crime of opinion, crimen opinionis; its competence extended only to the repression of organized conspiracy against public order and the common good. It was, if you will, a Committee on un-Christian Activities; it regarded activities, not ideas, as justiciable.

The American proposition, in reviving the distinction between society and state, which had perished under the advance of absolutism, likewise renewed the principle of the incompetence of government in the field of opinion. Government submits itself to judgment by the truth of society; it is not itself a judge of the truth in society. Freedom of the means of communication whereby ideas are circulated and criticized, and the freedom of the academy (understanding by the term the range of institutions organized for the pursuit of truth and the perpetuation of the intellectual heritage of society) are immune from legal inhibition or government control. This immunity is a civil right of the first order, essential to the American concept of a free people under a limited government.

\section{A Virtuous People}

"A free people": this term too has a special sense in the American proposition. America has passionately pursued the ideal of freedom, expressed in a whole system of political and civil rights, to new lengths; but it has not pursued this ideal so madly as to rush over the edge of the abyss, into sheer libertarianism, into the chaos created by the nineteenth-century theory of the "outlaw conscience," conscientia exlex, the conscience that knows no law higher than its own subjective imperatives. Part of the inner architecture of the American ideal of freedom has been the profound conviction that 
only a virtuous people can be free. It is not an American belief that free government is inevitable, only that it is possible, and that its possibility can be realized only when the people as a whole are inwardly governed by the recognized imperatives of the universal moral law.

The American experiment reposes on Acton's postulate, that freedom is the highest phase of civil society. But it also reposes on Acton's further postulate, that the elevation of a people to this highest phase of social life supposes, as its condition, that they understand the ethical nature of political freedom. They must understand, in Acton's phrase, that freedom is "not the power of doing what we like, but the right of being able to do what we ought." The people claim this right, in all its articulated forms, in the face of government; in the name of this right, multiple limitations are put upon the power of government. But the claim can be made with the full resonance of moral authority only to the extent that it issues from an inner sense of responsibility to a higher law. In any phase civil society demands order; in its highest phase of freedom it demands that order should not be imposed from the top down, as it were, but should spontaneously flower outward from free obedience to the restraints and imperatives that stem from inwardly possessed moral principle. In this sense democracy is more than a political experiment; it is a spiritual and moral enterprise. And its success depends upon the virtue of the people who undertake it. Men who would be politically free must discipline themselves. Likewise institutions which would pretend to be free with a human freedom must in their workings be governed from within and made to serve the ends of virtue. Political freedom is endangered in its foundations as soon as the universal moral values, upon whose shared possession the self-discipline of a free society depends, are no longer vigorous enough to restrain the passions and shatter the selfish inertia of men. The American ideal of freedom as ordered freedom, and therefore an ethical ideal, has traditionally reckoned with these truths, these truisms.

\section{Human and Historical Rights}

This brings us to the threshold of religion, and therefore to the other aspect of the problem of pluralism, the plurality of religions in 
America. However, before crossing this threshold one more characteristic of the American proposition, as implying a consensus, needs mention, namely, the Bill of Rights. The philosophy of the Bill of Rights was also tributary to the tradition of natural law, to the idea that man has certain original responsibilities precisely as man, antecedent to his status as citizen. These responsibilities are creative of rights which inhere in man antecedent to any act of government; therefore they are not granted by government and they cannot be surrendered to government. They are as inalienable as they are inherent. Their proximate source is in nature, and in history insofar as history bears witness to the nature of man; their ultimate source, as the Declaration of Independence states, is in God, the Creator of nature and the Master of history. The power of this doctrine, as it inspired both the Revolution and the form of the Republic, lay in the fact that it drew an effective line of demarcation around the exercise of political or social authority. When government ventures over this line, it collides with the duty and right of resistance. Its authority becomes arbitrary and therefore nil; its act incurs the ultimate anathema, "unconstitutional."

One characteristic of the American Bill of Rights is important for the subject here, namely, the differences that separate it from the Declaration of the Rights of Man in the France of '89. In considerable part the latter was a parchment-child of the Enlightenment, a top-of-the-brain concoction of a set of men who did not understand that a political community, like man himself, has roots in history and in nature. They believed that a state could be simply a work of art, a sort of absolute beginning, an artifact of which abstract human reason could be the sole artisan. Moreover, their exaggerated individualism had shut them off from a view of the organic nature of the human community; their social atomism would permit no institutions or associations intermediate between the individual and the state.

In contrast, the men who framed the American Bill of Rights understood history and tradition, and they understood nature in the light of both. They too were individualists, but not to the point of ignoring the social nature of man. They did their thinking within the tradition of freedom that was their heritage from England. Its roots were not in the top of anyone's brain but in history. Importantly, 
its roots were in the medieval notion of the homo liber et legalis, the man whose freedom rests on law, whose law was the age-old custom in which the nature of man expressed itself, and whose lawful freedoms were possessed in association with his fellows. The rights for which the colonists contended against the English Crown were basically the rights of Englishmen. And these were substantially the rights written into the Bill of Rights.

Of freedom of religion there will be question later. For the rest, freedom of speech, assembly, association, and petition for the redress of grievances, security of person, home, and property - these were great historical as well as civil and natural rights. So too was the right to trial by jury, and all the procedural rights implied in the Fifth- and later in the Fourteenth-Amendment provision for "due process of law." The guarantee of these and other rights was new in that it was written, in that it envisioned these rights with an amplitude, and gave them a priority, that had not been known before in history. But the Bill of Rights was an effective instrument for the delimitation of governmental authority and social power, not because it was written on paper in 1789 or 1791, but because the rights it proclaims had already been engraved by history on the conscience of a people. The American Bill of Rights is not a piece of eighteenthcentury rationalist theory; it is far more the product of Christian history. Behind it one can see, not the philosophy of the Enlightenment but the older philosophy that had been the matrix of the common law. The "man" whose rights are guaranteed in the face of law and government is, whether he knows it or not, the Christian man, who had learned to know his own personal dignity in the school of Christian faith.

\section{The American Consensus Today}

Americans have been traditionally devoted to the principles and ideas, the values and sentiments that pervaded the earlier phases of their history-colonial and Revolutionary, constitutional and Federalist. This devotion persists today. The question is, whether the American consensus still endures-the consensus whose essential contents have been sketched in the foregoing. A twofold answer may be given. The first answer is given by Professor Rossiter:

Perhaps Americans could achieve a larger measure of liberty and pros- 
perity and build a more successful government if they were to abandon the language and assumptions of men who lived almost two centuries ago. Yet the feeling cannot be downed that rude rejection of the past, rather than levelheaded respect for it, would be the huge mistake. Americans may eventually take the advice of their advanced philosophers and adopt a political theory that pays more attention to groups, classes, public opinion, powerélites, positive law, public administration, and other realities of twentiethcentury America. Yet it seems safe to predict that the people, who occasionally prove themselves wiser than their philosophers, will go on thinking about the political community in terms of unalienable rights, popular sovereignty, consent, constitutionalism, separation of powers, morality, and limited government. The political theory of the American Revolution-a theory of ethical, ordered liberty-remains the political tradition of the American people.

This answer is given in the name of the people as a whole. It implies that the original American consensus, which wrought the unity of the American people, still substantially endures, and still effects what it originally effected, the unity of the American body politic. Pace the advanced philosophers and their positivist philosophy (which, incidentally, is now beginning to seem, not advanced but rather "dated" and even reactionary), I think the implication is correct.

A second and corroborative answer is certainly valid of a not inconsiderable portion of the American people, the Catholic community. The men of learning in it acknowledge certain real contributions made by positive sociological analysis of the political community. But both they and their less learned fellows still adhere, with all the conviction of intelligence, to the tradition of natural law as the basis of free and ordered political life. Historically, this tradition has found, and still finds, its intellectual home within the Catholic Church. It is indeed one of the ironies of history that the tradition should have so largely languished in the so-called Catholic nations of Europe at the same time that its enduring vigor was launching a new Republic across the broad ocean. There is also some paradox in the fact that a nation which has (rightly or wrongly) thought of its own genius in Protestant terms should have owed its origins and the stability of its political structure to a tradition whose genius is alien to current intellectualized versions of the Protestant religion, and even to certain individualistic exigencies of Protestant 
religiosity. These are special questions, not to be pursued here. The point here is that Catholic participation in the American consensus has been full and free, unreserved and unembarrassed, because the contents of this consensus - the ethical and political principles drawn from the tradition of natural law - approve themselves to the Catholic intelligence and conscience. Where this kind of language is talked, the Catholic joins the conversation with complete ease. It is his language. The ideas expressed are native to his own universe of discourse. Even the accent, being American, suits his tongue.

It may be that another idiom will prevail. The possibility was inherent from the beginning. To the early American theorists and politicians the tradition of natural law was an inheritance. This was its strength; this was at the same time its weakness, especially since a subtle alteration of the tradition had already commenced. For a variety of reasons the intellectualist idea of law as reason had begun to cede to the voluntarist idea of law as will. One can note the change in Blackstone, for instance, even though he still stood within the tradition, and indeed drew whole generations of early American lawyers into it with him. (Part of American folklore is Sandburg's portrait of Abraham Lincoln, sitting barefoot on his woodpile, reading Blackstone.) Protestant Christianity, especially in its left wing (and its left wing has always been dominant in America), inevitably evolved away from the old English and American tradition. Grotius and the philosophers of the Enlightenment had cast up their secularized version of the tradition; their disciples were to better their instruction, as the impact of the methods of empirical science made itself felt even in those areas of human thought in which knowledge is noncumulative and to that extent recalcitrant to the methods of science. Seeds of dissolution were already present in the ancient heritage as it reached the shores of America.

Perhaps the dissolution will one day be consummated. Perhaps one day the noble many-storeyed mansion of democracy will be dismantled, levelled to the dimensions of a flat majoritarianism, which is no mansion but a barn, perhaps even a tool shed in which the weapons of tyranny may be forged. Perhaps there will one day be wide dissent from the political principles which emerge from natural law, and dissent too from the constellation of ideas that have historically undergirded these principles - the idea that government has 
a moral basis, that the universal moral law is the foundation of society, that the legal order of society - that is, the state-is subject to judgment by a law that is not statistical but inherent in the nature of man; that the eternal reason of God is the ultimate origin of all law; that this nation in all its aspects-as a society, a state, an ordered and free relationship between governors and governed-is under God. The possibility that widespread dissent from these principles should develop is not foreclosed. If that evil day should come, the results would introduce one more paradox into history. The Catholic community would still be speaking in the ethical and political idiom familiar to them, as it was familiar to their fathers, both the Fathers of the Church and the Fathers of the American Republic. The guardianship of the original American consensus, based on the Western heritage, would have passed to the Catholic community, within which the heritage was elaborated long before America was. And it would be for others, not Catholics, to ask themselves whether they still shared the consensus which first fashioned the American people into a body politic and determined the structure of its fundamental law.

What has been said may suffice to show the grounds on which Catholics participate in the American consensus. These grounds are drawn from the materials of the consensus itself. It has been a greatly providential blessing that the American Republic never put to the Catholic conscience the questions raised, for instance, by the Third French Republic. There has never been a schism within the American Catholic community, as there was among French Catholics, over the right attitude to adopt toward the established polity. There has never been the necessity for nice distinctions between the regime and the legislation; nor has there ever been the need to proclaim a policy of ralliement. In America the ralliement has been original, spontaneous, universal. It has been a matter of conscience and conviction, because its motive was not expediency in the narrow sensethe need to accept what one is powerless to change. Its motive was the evident coincidence of the principles which inspired the American Republic with the principles that are structural to the Western Christian political tradition.

The second question concerns the American solution to the problem 
put by the plurality of conflicting religions within the one body politic. In its legal form the solution is stated in the First Amendment to the Federal Constitution: "Congress shall make no law respecting an establishment of religion, or prohibiting the free exercise thereof. ..."

\section{Plurality Amid Unity}

In 1790 Edmund Burke published his Reflections on the Revolution in France. When he comes to his defense of English institutions ("an established Church, an established monarchy, an established aristocracy, and an established democracy"), he says: "First I beg leave to speak of our Church Establishment, which is the first of our prejudices - not a prejudice destitute of reason, but involving in it profound and extensive wisdom. I speak of it first. It is first, and last, and midst in our minds." In that same year the people of the states newly formed into the American Federal Republic were debating the ten amendments to the Constitution, submitted to them for ratification. The ratification was complete in 1791, and in that year the legal rule against any establishment of religion was on its way to becoming, where it had not already become, the first of our prejudices. There is a contrast here, a clash of prejudices, which still endures. The clash ought to be mentioned at the outset of our present question, primarily because it should teach one the dangers of doctrinaire judgments. Such judgments are always in peril of falsity; they are particularly so in the delicate matter of the legal regulation of religion in society. We have a special prejudice in this matter, which is specifically American, because its origins are in our particular context and its validity has been demonstrated by the unique course of American history.

The subject might almost be left right here, if it could be generally admitted that the First Amendment expresses simply an American prejudice, in Burke's sense of the word. A prejudice is not necessarily an error; to be prejudiced is not necessarily to be unreasonable. Certain pre-judgments are wholesome. Normally, they are concrete judgments of value, not abstract judgments of truth. They are not destitute of reason, but their chief corroboration is from experience. They are part of the legacy of wisdom from the past; they express an ancestral consensus. Hence they supply in the present, as Russell Kirk puts it, "the half-intuitive knowledge which enables men to meet 
the problems of life without logic-chopping." The American Catholic is entirely prepared to accept our constitutional concept of freedom of religion and the policy of no establishment as the first of our prejudices. He is also prepared to admit that other prejudices may obtain elsewhere - in England, in Sweden, in Spain. Their validity in their own context and against the background of the history that generated them does not disturb him in his conviction that his own prejudice, within his own context and against the background of his own history, has its own validity.

American Catholics would even go as far as to say of the provisions of the First Amendment what Burke said of the English Church Establishment, that they consider it as "essential to their state; not as a thing heterogeneous and separable, something added from accommodation, what they may either keep up or lay aside, according to their temporary ideas of convenience. They consider it as the foundation of their whole Constitution, with which, and with every part of which, it holds an indissoluble union." The prejudice formulated in the First Amendment is but the most striking aspect of the more fundamental prejudice that was the living root of our constitutional system - the prejudice in favor of the method of freedom in society and therefore the prejudice in favor of a government of limited powers, whose limitations are determined by the consent of the people. The American people exempted from their grant of power to government any power to establish religion or to prohibit the free exercise thereof. The Catholic community, in common with the rest of the American people, has historically consented to this political and legal solution to the problem created by the plurality of religious beliefs in American society. They agree that the First Amendment is by no means destitute of reason; that it involves profound and extensive wisdom; that its wisdom has been amply substantiated by history. Consequently, they share the general prejudice which it states; often enough both in action and in utterances they have made this fact plain. And that should be the end of the matter.

\section{Theologies of the First Amendment}

But, as it happens, one is not permitted thus simply to end the matter. I leave aside the practical issues that have arisen concerning 
the application of the First Amendment. The question here is one of theory, the theory of the First Amendment in itself and in its relation to Catholic theories of freedom of religion and the Church-State relation. It is customary to put to Catholics what is supposed to be an embarrassing question: Do you really believe in the first two provisions of the First Amendment? The question calls to mind one of the more famous among the multitudinous queries put by Boswell to Dr. Johnson, "whether it is necessary to believe all the Thirty-Nine Articles." And the Doctor's answer has an applicable point: "Why, sir, that is a question which has been much agitated. Some have held it necessary that they should all be believed. Others have considered them to be only articles of peace, that is to say, you are not to preach against them."

An analogous difference of interpretation seems to exist with regard to the first two articles of the First Amendment. On the one hand there are those who read into them certain ultimate tenets, certain specifically sectarian tenets with regard to the nature of religion, religious truth, the church, faith, conscience, divine revelation, human freedom, etc. In this view these articles are invested with a genuine sanctity, that derives from their religious content. They are dogmas, norms of orthodoxy, to which one must conform on pain of some manner of excommunication. They are true articles of faith. Hence it is necessary to believe them, to give them a religiously motivated assent. On the other hand there are those who see in these articles only a law, not a dogma. These constitutional clauses have no religious content; they answer none of the eternal human questions with regard to the nature of truth and freedom or the manner in which the spiritual order of man's life is to be organized or not organized. Therefore they are not invested with the sanctity that attaches to dogma, but only with the rationality that attaches to law. Rationality is the highest value of law. In further consequence it is not necessary to give them a religious assent but only a rational civil obedience. In a word they are not articles of faith but articles of peace, that is to say, you may not act against them, because they are law and good law.

Those who dogmatize about these articles do not usually do so with all the clarity that dogmas require. Nor are they in agreement with one another. The main difference is between those who see in these 
articles certain Protestant religious tenets and those who see in them certain ultimate suppositions of secular liberalism. The differences between those two groups tend to disappear in a third group, the secularizing Protestants, so called, who effect an identification of their Protestantism with American secular culture, consider the church to be true in proportion as its organization is commanded by the norms of secular democratic society, and bring about a coincidence of religious and secular-liberal concepts of freedom. All three of these currents of thought have lengthy historical roots; the first, predominantly in the modified Puritan Protestantism of the "free church" variety; the second, in early American deism and rationalism; the third, in less specific sources, but importantly in the type of Protestantism, peculiar to America, whose character was specified during the Great Awakening, when the American climate did as much to influence Protestantism as Protestantism did to influence the American climate. This more radical secularizing Protestantism has in common with the later Puritan tradition the notion that American democratic institutions are the necessary secular reflection of Protestant anti-authoritarian religious individualism and its concept of the "gathered" church. Protestantism and Americanism, it is held, are indissolubly wedded as respectively the religious and the secular aspects of the one manner of belief, the one way of life.

This is not the place to argue the question, whether and how far any of these views can be sustained as an historical thesis. What matters here is a different question, whether any of them can serve as a rule of interpretation of the First Amendment. What is in question is the meaning and the content of the first of our American prejudices, not its genesis. Do these clauses assert or imply, after the fashion of Roger Williams for instance, that the nature of the church is such that it inherently demands the most absolute separation from the state? Do they assert or imply, after the general freechurch fashion, that the institutional church is simply a voluntary association of like-minded men; that its origins are only in the will of men to associate freely for purposes of religion and worship; that all churches, since their several origins are in equally valid religious inspirations, stand on a footing of equality in the face of the divine and evangelical law; that all ought by the same token to stand on an equal footing in the face of civil law? In a word, does separation 
of church and state in the American sense assert or imply a particular sectarian concept of the church?

Further, does the free-exercise clause assert or imply that the individual conscience is the ultimate norm of religious belief in such wise that an external religious authority is inimical to Christian freedom? Does it, after the fashion of Jefferson, hold that religion is a purely private matter in such wise that an ecclesiastical religion is inherently a corruption of the Christian Gospel? Does it maintain that true religion is religion-in-general, and that the various sects in their dividedness are as repugnant religiously as they are politically dangerous? Does it pronounce religious truth to be simply a matter of personal experience, and religious faith to be simply a matter of subjective impulse, not related to any objective order of truth or to any structured economy of salvation whose consistence is not dependent on the human will?

The questions could be multiplied, but they all reduce themselves to two: Is the no-establishment clause a piece of ecclesiology, and is the free-exercise clause a piece of religious philosophy? The general Protestant tendency, visible at its extreme in the free-church tradition, especially among the Baptists, is to answer affirmatively to these questions. Freedom of religion and separation of church and state are to be, in the customary phrase, "rooted in religion itself." Their substance is to be conceived in terms of sectarian Protestant doctrine. They are therefore articles of faith; not to give them a religious assent is to fall into heterodoxy.

The secularist dissents from the Protestant theological and philosophical exegesis of the first of our prejudices. But it is to him likewise an article of faith (he might prefer to discard the word, "faith," and speak rather of ultimate presuppositions). Within this group also there are differences of opinion. Perhaps the most sharpened view is taken by those who in their pursuit of truth reject not only the traditional methods of Christian illumination, both Protestant and Catholic, but also the reflective methods of metaphysical inquiry. These men commit themselves singly to the method of scientific empiricism. There is therefore no eternal order of truth and justice; there are no universal verities that require man's assent, no universal moral law that commands his obedience. Such an order of universals is not empirically demonstrable. Truth therefore is to 
be understood in a positivistic sense; its criteria are either those of science or those of practical life, i.e., the success of an opinion in getting itself accepted in the market place. With this view of truth there goes a corresponding view of freedom. The essence of freedom is "noncommittalism." I take the word from Gordon Keith Chalmers. He calls it a "sin," but in the school of thought in question it is the highest virtue. To be uncommitted is to be in the state of grace; for a prohibition of commitment is inherent in the very notion of freedom. The mind or will that is committed, absolutely and finally, is by definition not free. It has fallen from grace by violating its own nature. In the intellectual enterprise the search for truth, not truth itself or its possession, is the highest value. In the order of morals the norm for man is never reached by knowledge; it is only approximated by inspired guesses or by tentative practical rules that are the precipitate of experience, substantiated only by their utility.

This school of thought, which is of relatively recent growth in America, thrusts into the First Amendment its own ultimate views of truth, freedom and religion. Religion itself is not a value, except insofar as its ambiguous reassurances may have the emotional effect of reassuring. Roman Catholicism is a disvalue. Nevertheless, religious freedom, as a form of freedom, is a value. It has at least the negative value of an added emancipation, another sheer release. It may also have the positive value of another blow struck at the principle of authority in any of its forms; for in this school authority is regarded as absolutely antinomous to freedom.

Furthermore, this school usually reads into the First Amendment a more or less articulated political theory. Civil society is the highest societal form of human life; even the values that are called spiritual and moral are values by reason of their reference to society. Civil law is the highest form of law and it is not subject to judgment by prior ethical canons. Civil rights are the highest form of rights; for the dignity of the person, which grounds these rights, is only his civilty; civilty is humanity's highest perfection. The state is purely the instrumentality of the popular will, than which there is no higher sovereignty. Government is to the citizen what the cab-driver is to the passenger (to use Yves Simon's descriptive metaphor). And since the rule of the majority is the method whereby the popular will 
expresses itself, it is the highest governing principle of statecraft, from which there is no appeal. Finally, the ultimate value within society and state does not consist in any substantive ends that these societal forms may pursue; rather it consists in the process of their pursuit. That is to say, the ultimate value resides in the forms of the democratic process itself, because these forms embody the most ultimate of all values, freedom. There are those who pursue this theory to paradoxical lengths - perhaps more exactly, to the lengths of logical absurdity - by maintaining that if the forms of democracy perish through the use made of them by men intent on their destruction, well then, so be it.

Given this political theory, the churches are inevitably englobed within the state, as private associations organized for particular purposes which possess their title to existence from positive law. Their right to freedom is a civil right, and it is respected as long as it is not understood to include any claim to independently sovereign authority. Such a claim must be disallowed on grounds of the final and indivisible sovereignty of the democratic process over all the associational aspects of human life. The notion that any church should acquire status in public life as a society in its own right is per se absurd; for there is only one society, civil society, which may so exist. In this view, separation of church and state, as ultimately implying a subordination of church to state, follows from the very nature of the state and its law; just as religious freedom follows from the very nature of freedom and of truth.

The foregoing is a sort of anatomical description of two interpretations of the religion clauses of the First Amendment. The description is made anatomical in order to point the issue. If these clauses are made articles of faith in either of the described senses, there are immediately in this country some $30,000,000$ dissenters, the Catholic community. Not being either a Protestant or a secularist, the Catholic rejects the religious position of Protestants with regard to the nature of the church, the meaning of faith, the absolute primacy of conscience, etc.; just as he rejects secularist views with regard to the nature of truth, freedom, and civil society as man's last end. He rejects these positions as demonstrably erroneous in themselves. What is more to the point here, he rejects the notion that any of these 
sectarian theses enter into the content or implications of the First Amendment in such wise as to demand the assent of all American citizens. If this were the case the very article that bars any establishment of religion would somehow establish one. (Given the controversy between Protestant and secularist, there would be the added difficulty that one could not know just what religion had been established.) If it be true that the First Amendment is to be given a theological interpretation and that therefore it must be "believed," made an object of religious faith, it would follow that a religious test has been thrust into the Constitution. The Federal Republic has suddenly become a voluntary fellowship of believers either in some sort of free-church Protestantism or in the tenets of a naturalistic humanism. The notion is preposterous. The United States is an awfully good place to live in; many have found it even a sort of secular sanctuary. But it is not a church, whether high, low, or broad. It is simply a civil community, whose unity is purely political, consisting in "agreement on the good of man at the level of performance without the necessity of agreement on ultimates" (to adopt a phrase from the 1945 Harvard Report on General Education in a Free Society). As regards important points of ultimate religious belief, the United States is pluralist. Any attempt at reducing this pluralism by law, through a process of reading certain sectarian tenets into the fundamental law of the land, is prima facie illegitimate and absurd.

Theologians of the First Amendment, whether Protestant or secularist, are accustomed to appeal to history. They stress the importance of ideological factors in the genesis of the American concept of freedom of religion and separation of church and state. However, these essays in theological history are never convincing. In the end it is always Roger Williams to whom appeal is made. Admittedly, he was the only man in pre-Federal America who had a consciously articulated theory. The difficulty is that the Williams who is appealed to is a Williams who never was. Prof. Perry Miller's recent book, Roger Williams, is useful in this respect. Its citations and analyses verify the author's statement: "I have long been persuaded that accounts written in the last century create a figure admirable by the canons of modern secular liberalism, but only distantly related to the actual Williams." The unique genius of 
Master Roger has been badly obscured by historians of a longdominant school, now in incipient decline, who tended to see early American history through the climate of opinion generated by the Enlightenment. Their mistake lay in supposing that the haze of this climate actually hung over the early American landscape, whereas in fact it only descended, long after, upon the American universities within which the historians did their writing.

Professor Miller's book enhances the moral grandeur and human attractiveness of Roger Williams. It further makes clear, largely by letting him speak for himself, that he was no child of the Enlightenment born before his time. He was a seventeenth-century Calvinist who somehow had got hold of certain remarkably un-Calvinist ideas on the nature of the political order in its distinction from the church. He then exaggerated this distinction in consequence of his special concept of the discontinuity of the Old and New Testaments and of the utter transcendence of the church in the New Testament, which forbids it to maintain any contacts with the temporal order. In any event, Williams' premises and purposes were not those of the secular liberal democrat, any more than his rigidly orthodox Calvinist theology is that of his Baptist progeny. (One can imagine his horror were he to hear the Reverend Joseph Martin Dawson, today's outstanding Baptist spokesman, utter with prideful satisfaction the phrase, "the Americanization of the churches").

However, this is not the place to explore Williams' ideas, ecclesiastical or political. The point is that his ideas, whatever their worth, had no genetic influence on the First Amendment. Professor Miller makes the point: "Hence, although Williams is celebrated as the prophet of religious freedom, he actually exerted little or no influence on institutional developments in America; only after the conception of liberty for all denominations had triumphed on wholly other grounds did Americans look back on Williams and invest him with his ill-fitting halo." Williams therefore is to be ruled out as the original theologian of the First Amendment. In fact, one must rule out the whole idea that any theologians stood at the origin of this piece of legislation. The truth of history happens to be more prosaic than the fancies of the secular liberals. In seeking an understanding of the first of our prejudices we have to abandon the poetry of those who would make a religion out of freedom of religion and a dogma 
out of separation of church and state. We have to talk prose, the prose of the Constitution itself, which is an ordinary legal prose having little to do with doctrinaire theories.

\section{Articles of Peace}

From the standpoint both of history and of contemporary social reality the only tenable position is that the first two articles of the First Amendment are not articles of faith but articles of peace. Like the rest of the Constitution these provisions are the work of lawyers, not of theologians or even of political theorists. They are not true dogma but only good law; that is praise enough. This, I take it, is the Catholic view. But in thus qualifying it I am not marking it out as just another "sectarian" view. It is in fact the only view that a citizen with both historical sense and common sense can take.

That curiously clairvoyant statesman, John C. Calhoun, once observed that "this admirable federal constitution of ours is superior to the wisdom of any or all of the men by whose agency it was made. The force of circumstances and not foresight or wisdom induced them to adopt many of its wisest provisions." The observation is particularly pertinent to the religion clauses of the First Amendment. If history makes one thing clear it is that these clauses were the twin children of social necessity, the necessity of creating a social environment, protected by law, in which men of differing religious faiths might live together in peace. In his stimulating book, The Genius of American Politics, Prof. Daniel Boorstin says: "The impression which the American has as he looks about him is one of the inevitability of the particular institutions under which he lives." This mark of inevitability is likewise the mark of goodness. And it is perhaps nowhere more strikingly manifest than in the institutions which govern the relation of government to religion. These institutions seem to have been preformed in the peculiar conditions of American society. It did indeed take some little time before the special American solution to the problem of religious pluralism worked itself out; but it is almost inconceivable that it should not have worked itself out as it did. One suspects that this would have been true even if there had been no Williamses and Penns, no Calverts and Madisons and Jeffersons. The theories of these men, whatever their merits, would probably have made only literature not 
history, had it not been for the special social context into which they were projected. Similarly, the theories of these men, whatever their defects, actually made history because they exerted their pressure, such as it was, in the direction in which historical factors were already moving the new American society.

To say this is not of course to embrace a theory of historical or social determinism. It is only to say that the artisans of the American Republic and its Constitution were not radical theorists intent on constructing a society in accord with the $a$ priori demands of a doctrinaire blueprint, under disregard for what was actually "given" in history. Fortunately they were, as I said, for the most part lawyers. And they had a strong sense of that primary criterion of good law which is its necessity or utility for the preservation of the public peace, under a given set of conditions. All law looks to the common good, which is normative for all law. And social peace, assured by equal justice in dealing with possibly conflicting groups, is the highest integrating element of the common good. This legal criterion is the first and most solid ground on which the validity of the First Amendment rests.

Every historian who has catalogued the historical factors which made for religious liberty and separation of church and state in America would doubtless agree that these institutions came into being under the pressure of their necessity for the public peace. Four leading factors, contributory to this social necessity, are usually listed. First, there was the great mass of the unchurched. They were either people cut off from religion by the conditions of frontier life; or people careless of religion in consequence of preoccupation with the material concerns of this world; or people concerned with religion as indispensable to morality and therefore to ordered civil life, but unconcerned with, or even hostile toward, what is called organized religion. The fact may be embarrassing to the highminded believer, but it is nevertheless a fact that the development of religious freedom in society bears a distinct relationship to the growth of unbelief and indifference. Our historical good fortune lay in the particular kind of unbelief that American society has known. It was not Continental laicism, superficially anticlerical, fundamentally antireligious, militant in its spirit, active in its purpose to destroy what it regarded as hateful. Unbelief in America 
has been rather easy-going, the product more of a naive materialism than of any conscious conviction. The American unbeliever is usually content to say, "I am not personally a religious man," and let the subject drop there. American unbelief is usually respectful of belief, or at least respectful of the freedom to believe. And this fact has been important in influencing the general climate in which our institutions work.

The second factor was the multiplicity of denominations. This was Protestantism's decisive contribution to the cause of religious freedom-decisive because made at a time when the rapidly proliferating denominations were less disposed than they now are to live together in peace. This fact made it necessary to seek a basis for political unity other than the hitherto prevailing one, agreement in religious faith and ecclesiastical polity. Figgis' famous dictum, "Political liberty is the residuary legatee of ecclesiastical animosities," is a historical half-truth. It is not the whole of the truth even in the matter of religious liberty. But the truth in it cannot be denied. In this sense the Cottons and the Mathers made their contribution to American freedom of religion no less, and perhaps more, than the Williamses and Penns. The sheer fact of dissent and sectarian antagonisms was a particularly important motive of the Federal constitutional arrangements; for at that time four states still retained establishments of various kinds. One recalls John Adams' testy reluctance to hear any argument about disestablishment in Massachusetts.

Thirdly, the economic factor was by no means unimportant. It was present in the somewhat impenetrable thinking of the two Calverts. The merchants of New Jersey, New York, Virginia and the more southern colonies were as emphatically on the side of religious freedom as on the side of commercial profits. Persecution and discrimination were as bad for business affairs as they were for the affairs of the soul.

A fourth factor of lesser importance was the pressure, not indeed very great but real enough, exerted by the widening of religious freedom in England. This growth had been fostered by the same factors that were operating more strongly in America. Anglicanism and Nonconformism were engaged in a struggle whose issue was already becoming clear. It was not to be disestablishment; Burke's 
prejudice, widely shared, would be too strong to permit that. But it would at least be religious freedom (except for Catholics), conjoined with establishment. In America, where the ground was clear for the creation of a new prejudice, the development could go all the way.

These four factors, taken as sociological complex, made it sufficiently clear to all reasonable men that under American conditions any other course but freedom of religion and separation of church and state would have been disruptive, imprudent, impractical, indeed impossible. The demands of social necessity were overwhelming. It remains only to insist that in regarding the religion clauses of the First Amendment as articles of peace and in placing the case for them on the primary grounds of their social necessity, one is not taking low ground. Such a case does not appeal to meanspirited expediency nor does it imply a reluctant concession to force majeure. In the science of law and the art of jurisprudence the appeal to social peace is an appeal to a high moral value. Behind the will to social peace there stands a divine and Christian imperative. This is the classic and Christian tradition.

Roger Williams himself was a powerful spokesman of it. "Sweet peace" (the phrase he uses in The Bloudy Tenent) stands at the center of his doctrine; and he adds in the same context that "if it be possible, it is the express command of God that peace be kept." In a letter of 1671 to John Cotton the younger he recalls with satisfaction that his second great work, The Bloudy Tenent Still More Bloudy was received in England "with applause and thanks" as "professing that of necessity, yea, of Christian equity, there could be no reconciliation, pacification, or living together but by permitting of dissenting consciences to live amongst them." There is also, along with others, the strong statement with which he concludes his pamphlet, The Hireling Ministry None of Christ's. As the sum of the matter he proclaims the duty of the civil state in the current conditions of religious division "to proclaim free and impartial liberty to all the people of the three nations to choose and maintain what worship and ministry their souls and consciences are persuaded of; which act, as it will prove an act of mercy and righteousness to the enslaved nations, so it is a binding force to engage the whole and every interest and conscience to preserve the common freedom 
and peace." This is the way whereby "civil peace and the beauty of civilty and humanity [may] be obtained among the chief opposers and dissenters."

Roger Williams was no partisan of the view that all religions ought to be equally free because, for all anybody knows, they may all be equally true, or false. He reckons with truth and falsity in honest fashion. Yet even in the case of a "false religion (unto which the civil magistrate dare not adjoin)" he recommends as the first duty of the civil magistrate "permission (for approbation he owes not what is evil) and this according to Matthew 13:30, for public peace and quiet's sake." The reference is the parable of the tares.

It is interesting that this same parable is referred to by Pius XII in his discourse to a group of Italian jurists on December 6, 1953. This discourse is the latest affirmation of the primacy of the principle of peace (or "union," which is the Pope's synonymous word) when it comes to dealing with the "difficulties and tendencies" which arise out of mankind's multiple pluralisms and dissensions. The "fundamental theoretical principle," says the Pope (and one should underscore the word, "theoretical"; it is not a question of sheer pragmatism, much less of expediency in the low sense), is this: "within the limits of the possible and the lawful, to promote everything that facilitates union and makes it more effective; to remove everything that disturbs it; to tolerate at times that which it is impossible to correct but which on the other hand must not be permitted to make shipwreck of the community from which a higher good is looked for." This higher good, in the context of the whole discourse, is "the establishment of peace."

From this firm footing of traditional principle the Pope proceeds to reject the view of certain Catholic theorists who in a sort of cutand-thrust manner would wish to "solve" the problem of religious pluralism on the ultimate basis of this doctrinaire argument: Religious and moral error have no rights and therefore must always be repressed when repression of them is possible. In contradiction of this view the Pope says, after quoting the parable of the tares: "The duty of repressing religious and moral error cannot therefore be an ultimate norm of action. It must be subordinated to higher and more general norms which in some circumstances permit, and even perhaps make it appear the better course of action, that error 
should not be impeded in order to promote a greater good." The Pope makes a clear distinction between the abstract order of ethics or theology, where it is a question of qualifying doctrines or practices as true or false, right or wrong, and the concrete order of jurisprudence, where it is a question of using or not using the coercive instrument of law in favor of the true and good, against the false and wrong. In this latter order the highest and most general norm is the public peace, the common good in its various aspects. This is altogether a moral norm.

Roger Williams had many a quarrel with the Roman papacy; in fact, he wanted it abolished utterly. It is therefore piquant in itself, and also a testimony to the strength of the hold that the central Christian tradition had upon him, to read this basic principle of Catholic teaching in the Bloudy Tenent: "It must be remembered that it is one thing to command, to conceal, to approve evil; and another thing to permit and suffer evil with protestation against it or dislike of it, at least without approbation of it. This sufferance or permission of evil is not for its own sake but for the sake of the good, which puts a respect of goodness upon such permission." The "good" here is the public peace. Williams concludes the passage thus: "And therefore, when it crosseth not an absolute rule to permit and tolerate (as in the case of the permission of the souls and consciences of all men of the world), it will not hinder our being holy as $\mathrm{He}$ is holy in all manner of conversation." In substance Pius XII says the same thing, that it crosseth not an absolute rule to permit within the civil community, as he says, "the free exercise of a belief and of a religious and moral practice which possesses validity" in the eyes of some of its members. In fact, the Pope goes much farther when he flatly states that "in certain circumstances God does not give men any mandate, does not impose any duty, and does not even communicate the right to impede or to repress what is erroneous and false." The First Amendment is simply the legal enunciation of this papal statement. It does not say that there is no distinction between true and false religion, good and bad morality. But it does say that in American circumstances the conscience of the community, aware of its moral obligations to the peace of the community, and speaking therefore as the voice of God, does not give government any mandate, does not impose upon it any duty, and does not even communicate 
to it the right to repress religious opinions or practices, even though they are erroneous and false.

On these grounds it is easy to see why the Catholic conscience has always consented to the religion clauses of the Constitution. They conform to the highest criterion for all legal rulings in this delicate matter. The criterion is moral; therefore the law that meets it is good, because it is for the common good. Therefore the consent given to the law is given on grounds of moral principle. To speak of expediency here is altogether to misunderstand the moral nature of the community and its collective moral obligation toward its own common good. The origins of our fundamental law are in moral principle; the obligations it imposes are moral obligations, binding in conscience. One may not, without moral fault, act against these articles of peace.

\section{The Distinction of Church and State}

If the demands of social necessity account for the emergence in America of religious freedom as a fact, they hardly account for certain peculiarities of the first of our prejudices and for the depth of feeling that it evokes. Another powerful historical force must be considered, namely, the dominant impulse toward self-government, government by the people in the most earnest sense of the word. Above all else the early Americans wanted political freedom. And the force of this impulse necessarily acted as a corrosive upon the illegitimate "unions" of church and state which the post-Reformation era had brought forth. The establishments of the time were, by and large, either theocratic, wherein the state was absorbed in the church, or Erastian, wherein the church was absorbed in the state. In both cases the result was some limitation upon freedom, either in the form of civil disabilities imposed in the name of the established religion, or in the form of religious disabilities imposed in the name of the civil law of the covenanted community. The drive toward popular freedom would with a certain inevitability sweep away such establishments. Men might share the fear of Roger Williams, that the state would corrupt the church, or the fear of Thomas Jefferson, that the church would corrupt the state. In either case their thought converged to the one important conclusion: an end had to be put to the current confusions of the religious and political orders; the 
ancient distinction between church and state had to be newly reaffirmed in a manner adapted to the American scene. Calvinist theocracy, Anglican Erastianism, Gallican absolutism-all were vitiated by the same taint: they violated in one way or another this traditional distinction. The dualism of mankind's two hierarchically ordered forms of social life had been Christianity's cardinal contribution to the Western political tradition, as everyone knows who has looked into the monumental work of the two Carlyles, Medieval Political Thought in the West. Perhaps equally with the very idea of law itself it had been the most fecund force for freedom in society. The distinction had always been difficult to maintain in practice, even when it was affirmed in theory. But when it was formally denied the result was an infringement of man's freedom of religious faith or of his freedom as a citizen - an infringement of either or both. Hence the generalized American impulse toward freedom inevitably led to a new and specially emphatic affirmation of the traditional distinction.

The distinction lay readily within the reach of the early American lawyers and statesmen; for it was part of the English legal heritage, part of the patrimony of the common law. One can see it appearing, for instance, in Madison's famous Memorial and Remonstrance, where it is interpreted in a manner conformable to the anti-ecclesiasticism which he had in common with Jefferson. But the interesting figure here is again Roger Williams. Reading him, the Catholic theorist is inclined to agree with those "juditious persons" whose verdict was reluctantly and belatedly recorded by Cotton Mather. They "judged him," said Mather, "to have the root of the matter in him." In the present question the root of the matter is this distinction of the spiritual and temporal orders and their respective jurisdictions. One is tempted to think that he got hold of this root at least partly because of his early acquaintance with English law; he was for a time secretary to the great Sir Edward Coke and it is at least not unlikely that he continued his legal interests at Cambridge. In any event, this distinction was a key principle with Williams; he had his own special understanding of it, but at least he understood it. What is more, in 1636 he felt in his own flesh, so to speak, the effects of its violations in the Massachusetts colony. Of his banishment from Massachusetts in that year he later wrote: "Secondly, if he (John Cotton) means this civil act of banishing, 
why should he call a civil sentence from a civil state, within a few weeks execution in so sharp a time of New England's cold, why should he call this a banishment from the churches except he silently confess that the frame or constitution of their churches is implicitly national (which yet they profess against)? For otherwise, why was I not yet permitted to live in the world or commonweal except for this reason, that the commonweal and church is yet but one, and he that is banished from the one must necessarily be banished from the other also?" This was his constant accusation against the New England Way. He says on another occasion: "First, it will appear that in spiritual things they make the garden and the wilderness (as I often have intimated), I say, the garden and the wilderness, the church and the world are all one." The same charge is lodged against "holy men, emperors and bishops" throughout history, that "they made the garden of the church and the field of the world to be all one...."

However erroneously Williams may have understood the "garden," the church, as having no roots whatsoever in the "wilderness," at least he knew that church and state are not one but two; to make them "all one" is to violate the nature of the church and also the nature of the state, as this latter had been understood in the liberal Christian political tradition.

As has been said Roger Williams was not a Father of the Federal Constitution; he is adduced here only as a witness, in his own way, to the genuine Western tradition of politics. The point is that the distinction of church and state, one of the central assertions of this tradition, found its way into the Constitution. There it received a special embodiment, adapted to the peculiar genius of American government and to the concrete conditions of American society. How this happened need not concern us. Certainly it was in part because the artisans of the Constitution had a clear grasp of the distinction between state and society, which had been the historical product of the distinction between church and state, inasmuch as the latter distinction asserted the existence of a whole wide area of human concerns which were remote from the competence of government. Calhoun's "force of circumstances" also had a great deal of influence; here again it was a matter of the Fathers building better than they knew. Their major concern was sharply to circumscribe the powers 
of government. The area of state - that is, legal-concern was limited to the pursuit of certain enumerated secular purposes (to say that the purposes are secular is not to deny that many of them are also moral; so for instance the establishment of justice and peace, the promotion of the general welfare, etc.). Thus made autonomous in its own sphere, government was denied all competence in the field of religion. In this field freedom was to be the rule and method; government was powerless to legislate respecting an establishment of religion and likewise powerless to prohibit the free exercise of religion. Its single office was to take the legal or judicial steps necessary on given occasions to make effective the guarantee of freedom.

The concrete applications of this in itself quite simple solution have presented great historical and legal difficulties. This has been inevitable, given the intimacy with which religion is woven into the whole social fabric, and given, too, the evolution of government from John Adams' "plain, simple, intelligible thing, quite comprehensible by common sense," to the enormously complicated and sprawling thing which now organizes a great part of our lives, handles almost all education, and much social welfare. In particular, we have not yet found an answer to the question whether government can make effective the primary intention of the First Amendment, the guarantee of freedom of religion, simply by attempting to make more and more "impregnable" what is called, in Rogers Williams' fateful metaphor, the "wall of separation" between church and state. However, what concerns us here is the root of the matter, the fact that the American Constitution embodies in a special way the traditional principle of the distinction between church and state. For Catholics this fact is of great and providential importance for one major reason: it serves sharply to set off our constitutional system from the system against which the Church waged its long-drawn-out fight in the nineteenth century, namely, Jacobinism, or (in Carlton Hayes's term) sectarian Liberalism, or (in the more definitive term used today) totalitarian democracy.

It is now coming to be recognized that the Church opposed the "separation of church and state" of the sectarian Liberals because in theory and in fact it did not mean separation at all but perhaps the most drastic unification of church and state which history had known. 
The Jacobin "free state" was as regalist as the ancien régime, and even more so. Writing as a historian, de Tocqueville long ago made this plain. And the detailed descriptions which Leo XIII, writing as a theologian and political moralist, gave of the Church's "enemy" make the fact even more plain. Within this "free state" the so-called "free church" was subject to a political control more complete than the Tudor or Stuart or Bourbon monarchies dreamed of. The evidence stretches all the way from the Civil Constitution of the Clergy in 1790 to the Law of Separation in 1905. In the system sponsored by the sectarian Liberals, as has been well said, "The state pretends to ignore the Church; in reality it never took more cognizance of her." In the law of 1905 , the climactic development, the Church was arrogantly assigned a juridical statute articulated in forty-four articles, whereby almost every aspect of her organization and action was minutely regulated. Moreover, this was done on principle - the principle of the primacy of the political, the principle of "everything within the state, nothing above the state." This was the cardinal thesis of sectarian Liberalism, whose full historical development is now being witnessed in the totalitarian "people's democracies" behind the Iron Curtain. As the Syllabus and its explicatory documents - as well as the multitudinous writings of Leo XIII-make entirely clear, it was this thesis of the juridical omnipotence and omnicompetence of the state which was the central object of the Church's condemnation of the Jacobin development. It was because freedom of religion and separation of church and state were predicated on this thesis that the Church refused to accept them in thesi, as the phrase has it.

This thesis was utterly rejected by the founders of the American Republic. The rejection was as warranted as it was providential, because this thesis is not only theologically heterodox, as denying the reality of the Church; it is also politically revolutionary, as denying the substance of the liberal tradition. The American thesis is that government is not juridically omnipotent; its powers are limited, and one of the principles of limitation is the distinction between state and church, in their purposes, methods, and manner of organization. The Jacobin thesis was basically philosophical; it derived from a sectarian concept of the autonomy of reason. It was also theological, as implying a sectarian concept of religion and of 
the church. In contrast, the American thesis is simply political; it asserts the theory of a free people under a limited government, a theory that is recognizably part of the Christian political tradition, and altogether defensible in the manner of its realization under American circumstances.

It may indeed be said that the American constitutional system exaggerates the distinction between church and state by its selfdenying ordinances. However, it must also be said that government rarely appears to better advantage than when passing self-denying ordinances. In any event, it is one thing to exaggerate a traditional distinction along the lines of its inherent tendency; it is quite another thing to abolish the distinction. In the latter case the result is a vicious monistic society; in the former, a faultily dualistic one. The vice in the Jacobin system could only be condemned by the Church, not in any way condoned. The fault in the American system can be recognized as such, without condemnation. There are times and circumstances, Chesterton jocosely said, when it is necessary to exaggerate in order to tell the truth. There are also times and circumstances, one may more seriously say, when some exaggeration of the restrictions placed on government is necessary in order to insure freedom. These circumstances of social necessity were and are present in America.

Here then is the second leading reason why the American solution to the problem of religious pluralism commends itself to the Catholic conscience. In the discourse already cited Pius XII states, as the two cardinal purposes of a Concordat, first, "to assure to the Church a stable condition of right and of fact within society," and second, "to guarantee to her a full independence in the fulfillment of her divine mission." It may be maintained that both of these objectives are sufficiently achieved by the religious provisions of the First Amendment. It is obvious that the Church in America enjoys a stable condition in fact. That her status at law is not less stable ought to be hardly less obvious, if only one has clearly in mind the peculiarity of the American affirmation of the distinction between church and state. This affirmation is made through the imposition of limits on government, which is confined to its own proper ends, those of temporal society. In contrast to the Jacobin system in all its forms, the American Constitution does not presume to define the Church or in 
any way to supervise her exercise of authority in pursuit of her own distinct ends. The Church is entirely free to define herself and to exercise to the full her spiritual jurisdiction. It is legally recognized that there is an area which lies outside the competence of government. This area coincides with the area of the divine mission of the Church, and within this area the Church is fully independent, immune from interference by political authority.

The juridical result of the American limitation of governmental powers is the guarantee to the Church of a stable condition of freedom as a matter of law and right. It should be added that this guarantee is made not only to the individual Catholic but to the Church as an organized society with its own law and jurisdiction. The reason is that the American state is not erected on the principle of the unity and indivisibility of sovereignty which was the post-Renaissance European development. Nowhere in the American structure is there accumulated the plenitude of legal sovereignty possessed in England by the Queen in Parliament. In fact, the term "legal sovereignty" makes no sense in America, where sovereignty (if the alien term must be used) is purely political. The United States has a government, or better, a structure of governments operating on different levels. The American state has no sovereignty in the classic Continental sense. Within society, as distinct from the state, there is room for the independent exercise of an authority which is not that of the state. This principle has more than once been affirmed by American courts, most recently by the Supreme Court in the Kedroff case. The validity of this principle strengthens the stability of the Church's condition at law.

Perhaps the root of the matter, as hitherto described, might be seen summed up in an incident of early American and Church history. This is Leo Pfeffer's account of it:

In 1783 the papal nuncio at Paris addressed a note to Benjamin Franklin suggesting that, since it was no longer possible to maintain the previous status whereunder American Catholics were subject to the Vicar Apostolic at London, the Holy See proposed to Congress that a Catholic bishopric be established in one of the American cities. Franklin transmitted the note to the [Continental] Congress, which directed Franklin to notify the nuncio that "the subject of his application to Doctor Franklin being purely spiritual, it is without the jurisdiction and powers of Congress, who have no authority to 
permit or refuse it, these powers being reserved to the several states individually." (Not many years later the several states would likewise declare themselves to "have no authority to permit or refuse" such a purely spiritual exercise of ecclesiastical jurisdiction.)

The good Nuncio must have been mightily surprised on receiving this communication. Not for centuries had the Holy See been free to erect a bishopric and appoint a bishop without the prior consent of government, without prior exercise of the governmental right of presentation, without all the legal formalities with which the so-called Catholic states had fettered the freedom of the Church. In the United States the freedom of the Church was completely unfettered; she could organize herself with the full independence which is her native right. This, it may be confidently said, was a turning point in the long and complicated history of Church-State relations.

\section{The American Experience}

One final ground for affirming the validity of the religion clauses of the First Amendment as good law must be briefly touched on. Holmes's famous dictum, "The life of the law is not logic but experience," has more truth in it than many other Holmesian dicta. When a law ceases to be supported by a continued experience of its goodness, it becomes a dead letter, an empty legal form. Although pure pragmatism cannot be made the philosophy of law, nonetheless the value of any given law is importantly pragmatic. The First Amendment surely passes this test of good law. In support of it one can adduce an American experience. One might well call it the American experience in the sense that it has been central in American history and also unique in the history of the world.

This experience has three facets, all interrelated. First, America has proved by experience that political unity and stability are possible without uniformity of religious belief and practice, without the necessity of any governmental restrictions on any religion. Before the days of the Federal Republic some men had tried to believe that this could be so; thus for instance the politiques in France, in their attack upon the classic Gallican and absolutist thesis, "One law, one faith, one king." But this thesis, and its equivalents, had not been finally disproved. This event was accomplished in the United States; and the refutation has been furnished by a manner of 
argument which is itself irrefutable - an argument from experience. For a century and a half the United States has displayed to the world the fact that political unity and stability are not inherently dependent on the common sharing of one religious faith. If therefore such a dependence elsewhere exists, it must be explained not in terms of inherent necessity but in terms of particular circumstances. Such circumstances may exist, for instance, in Spain; and undoubtedly the Spaniard must be allowed to argue from his own experience. But it should be made plain that he is arguing from the experience of his own history, and not from the inherent nature of things - the nature of political unity in its relation to religious unity.

The second American experience was that stable political unity, which means perduring agreement on the common good of man at the level of performance, is positively strengthened by the exclusion of religious differences from the area of concern allotted to government. In America we have been rescued from the disaster of ideological parties. They are a disaster because, where such parties exist, power becomes a special kind of prize: the struggle for power is a partisan struggle for the means whereby the opposing ideology may be destroyed. It has been remarked that only in a disintegrating society does politics become a controversy over ends; it should be simply a controversy over means to ends already agreed on with sufficient unanimity. The Latin countries of Europe have displayed this spectacle of ideological politics, a struggle between a host of "isms," all of which pretend to a final view of man and society, with the twin results of governmental paralysis and seemingly irremediable social division. In contrast, the American experience of political unity has been almost Utopian. (Even the Civil War does not refute this view; it was not an ideological conflict but simply, in the more descriptive Southern phrase, a war between the states, a conflict of interests.) To this experience of political unity the First Amendment has made a unique contribution; and in doing so it has qualified as good law.

The third and most striking aspect of the American experience consists in the fact that religion itself, and not least the Catholic Church, has benefited by our free institutions, by the maintenance, even in exaggerated form, of the distinction between Church and state. Within the same span of history the experience of the Church elsewhere, especially in the Latin lands, has been alternatively an 
experience of privilege or persecution. The reason lay in a particular concept of government. It was alternatively the determination of government to ally itself either with the purposes of the Church or with the purposes of some sect or other (sectarian Liberalism, for instance) which made a similar, however erroneous, claim to possess the full and final truth. The dominant conviction, whose origins are really in pagan antiquity, was that government should represent transcendent truth and by its legal power make this truth prevail. However, in the absence of social agreement as to what the truth really was, the result was to involve the Catholic truth in the vicissitudes of power. It would be difficult to say which experience, privilege or persecution, proved in the end to be the more damaging or gainful to the Church.

In contrast, American government has not undertaken to represent transcendental truth in any of the versions of it current in American society. It does indeed represent the commonly shared moral values of the community. It also represents the supreme religious truth expressed in the motto on American coins: "In God we trust"; the motto expresses the two truths without which, as the Letter to the Hebrews says, "nobody reaches God's presence," namely, "to believe that God exists and that he rewards those who try to find him" (Hebrews 11:6). For the rest, government represents the truth of society as it actually is; and the truth is that American society is religiously pluralist. The truth is lamentable; it is nonetheless true. Many of the beliefs entertained within society ought not to be believed, because they are false; nonetheless men believe them. It is not the function of government to resolve the dispute between conflicting truths, all of which claim the final validity of transcendence. As representative of a pluralist society, wherein religious faith isas it must be-free, government undertakes to represent the principle of freedom.

In taking this course American government would seem to be on the course set by Pius XII for the religiously pluralist international community, of which America offers, as it were, a pattern in miniature. In the discourse already cited he distinguishes two questions: "The first concerns the objective truth and the obligation of conscience toward that which is objectively true and good." This question, he goes on, "can hardly be made the object of discussion and ruling 
among the individual states and their communities, especially in the case of a plurality of religious confessions within the same community." In other words, government is not a judge of religious truth; parliaments are not to play the theologian. In accord with this principle American government does not presume to discuss, much less rule upon, the objective truth or falsity of the various religious confessions within society. It puts to itself only Pius XII's second question, which concerns "the practical attitude" of government in the face of religious pluralism. It answers this question by asserting that in the given circumstances it has neither the mandate nor the duty nor the right to legislate either in favor of or against any of the religious confessions existent in American society, which in its totality government must represent. It will therefore only represent their freedom, in the face of civil law, to exist, since they do in fact exist. This is precisely the practical attitude which Pius XII recognizes as right, as the proper moral and political course.

In consequence of this American concept of the representative function of government the experience of the Church in America, like the general American experience itself, has proved to be almost Utopian, when one scans it from the viewpoint of the value upon which the Church sets primary importance, namely, her freedom in the fulfillment of her spiritual mission to communicate divine truth and grace to the souls of men, and her equally spiritual mission of social justice and peace. The Church has not enjoyed a privileged status in public life; at the same time she has not had to pay the price of this privilege. A whole book could be written on the price of such legal privilege. Another book could be written on the value of freedom without privilege. In fact, both books have been written, on the metaphorical pages of history. And looking over his own continually unrolling historical manuscript the American Catholic is inclined to conclude that his is a valid book. It does not develop a doctrinaire thesis, but it does prove a point. The point is that the goodness of the First Amendment as constitutional law is manifested not only by political but also by religious experience. By and large (for no historical record is without blots) it has been good for religion, for Catholicism, to have had simply the right of freedom. This right is at the same time the highest of privileges, and it too has its price. But the price has not been envy and enmity, the coinage 
in which the Church paid for privilege. It has only been the price of sacrifice, labor, added responsibilities; and these things are redemptive.

\section{Conclusion}

In the final analysis any validation of the First Amendment as good law - no matter by whom undertaken, be he Protestant, Catholic, Jew, or secularist-must make appeal to the three arguments developed above: the demands of social necessity, the rightfulness within our own circumstances of the American manner of asserting the distinction between church and state, and the lessons of experience. Perhaps the last argument is the most powerful. It is also, I may add, the argument which best harmonizes with the general tone which arguments for our institutions are accustomed to adopt. In a curiously controlling way this tone was set by the Federalist papers. These essays were not political treatises after the manner of Hobbes and Hegel, Rousseau and Comte, or even John Locke. It has been remarked that in America no treatises of this kind have been produced; and it is probably just as well. The authors of the Federalist papers were not engaged in broaching a political theory universal in scope and application, a plan for an Ideal Republic of Truth and Virtue. They were arguing for a particular Constitution, a special kind of governmental structure, a limited ensemble of concrete laws, all designed for application within a given society. They were in the tradition of the Revolutionary thinkers who led a colonial rebellion, not in the name of a set of flamboyant abstractions, but in the name of the sober laws of the British Constitution which they felt were being violated in their regard. It has been pointed out that the only real slogan the Revolution produced was: "No taxation without representation." It has not the ring of a trumpet; its sound is more like the dry rustle of a lawyer's sheaf of parchment.

It is in the tone of this tradition of American political writing that one should argue for the First Amendment. The arguments will tend to be convincing in proportion as their key of utterance approaches a dry rustle and not a wild ring. The arguments here presented are surely dry enough. Perhaps they will not satisfy the doctrinaire, the theologizer. But they do, I think, show that the first of our prejudices is "not a prejudice destitute of reason, but involving in it profound 
and extensive wisdom." This is all that need be shown; it is likewise all that can be shown.

The Catholic Church in America is committed to this prejudice by the totality of her experience in American history. As far as I know, the only ones who doubt the firmness, the depth, the principled nature of this commitment are not Catholics. They speak without knowledge and without authority; and the credence they command has its origins in emotion. If perhaps what troubles them is the fact that the commitment is limited, in the sense that it is not to the truth and sanctity of a dogma but only to the rationality and goodness of a law, they might recall the story of Pompey. After the capture of Jerusalem in 63 в.c. he went to the Temple and forced his way into the Holy of Holies. To his intense astonishment he found it empty. He should not have been astonished; for the emptiness was the symbol of the absence of idolatry. It symbolized the essential truth of Judaism, that One is the Lord. Professor Boorstin, who recounts the tale, adds: "Perhaps the same surprise awaits the student of American culture [or, I add, the American Constitution] if he finally manages to penetrate the arcanum of our belief. And for a similar reason. Far from being disappointed, we should be inspired that in an era of idolatry, when so many nations have filled their sanctuaries with ideological idols, we have had the courage to refuse to do so."

The American Catholic is on good ground when he refuses to make an ideological idol out of religious freedom and separation of church and state, when he refuses to "believe" in them as articles of faith. He takes the highest ground available in this matter of the relations between religion and government when he asserts that his commitment to the religion clauses of the Constitution is a moral commitment to them as articles of peace in a pluralist society.

Entron's Note: This article was in its original form given as one of the five lectures on the Church and American Civilization which commemorated the fifty-year jubilee of the College of New Rochelle. 